\title{
Remittance income uncertainty and asset accumulation
}

\author{
Catalina Amuedo-Dorantes ${ }^{1}$ and Susan Pozo ${ }^{2^{*}}$
}

\author{
* Correspondence: \\ susan.pozo@wmich.edu \\ ${ }^{2}$ Department of Economics, Western \\ Michigan University, Kalamazoo, MI \\ 49008, USA \\ Full list of author information is \\ available at the end of the article
}

\begin{abstract}
While a sizable literature has concluded that remittances impact the expenditure patterns of households, we have a limited understanding of how the predictability of these money flows affect their usage by remittance-receiving households. Using data from Mexico, we find that both the size and the uncertainty of remittances raise asset accumulation among recipient households. These results suggest that both the level and the predictability of remittance income should be given full consideration in the analysis of household expenditure patterns and in the design of policies to leverage the most out of remittance inflows into developing economies.
\end{abstract}

JEL codes: F220, J200

Keywords: International remittances; Uncertainty; Household expenditures; Asset accumulation; Mexico

\section{Introduction}

A sizable literature has concluded that remittances, like migration, impact the expenditure patterns of households. A majority of these studies find that remittances favorably impact asset accumulation by increasing the share of spending on investment over consumption (e.g. Zarate-Hoyos 2004, Adams 2005, Mora and Taylor 2006, Airola 2007). Some find, in addition, that remittances shift household spending from less productive asset accumulation to more productive asset accumulation (Chiodi, Jaimovich and Montes-Rojas 2012). In this study, we explore an additional factor that shapes household expenditure patterns by examining how the uncertainty of remittance income affects the accumulation of human, physical and financial assets.

While it is important to understand how the level of transfers from family abroad affects household spending, it is also useful to ascertain how the predictability of such money inflows influences household spending. Some households receive remittances on a regular and predictable basis, e.g. they receive $\$ 200$ each and every month. Other households might receive the same overall level of transfers irregularly -when emigrants return home, when they have accumulated a sufficient sum to send to family members in the home country, or at other unpredictable intervals. Consequently, while one remittance-receiving household is able to forecast with reasonable precision the timing of future remittance inflows, another one might be unable to, even if in the end both households receive the same overall amount. We argue that, ceteris paribus, the expenditure pattern of the two households is likely to differ. Specifically, households

(c) 2014 Amuedo-Dorantes and Pozo; licensee Springer. This is an Open Access article distributed under the terms of the Creative Commons Attribution License (http://creativecommons.org/licenses/by/2.0), which permits unrestricted use, distribution, and reproduction in any medium, provided the original work is properly cited. 
with regular and predictable remittance inflows are more likely to use those funds to meet ordinary, perhaps scheduled, consumption needs. In contrast, households that receive remittances on an irregular and less predictable basis are more likely to use those funds toward the accumulation of assets ${ }^{1}$. This hypothesized behavior follows from the life-cycle permanent income hypothesis (LCPIH), according to which regular and permanent increases in income tend to be consumed as individuals can expect to enjoy those income increments over the long term. The expectation of an increase in income over the long-run allows for an upward adjustment of consumption over the lifecycle. In contrast, irregular increases in income are less likely to be viewed as permanent. Since households cannot count on them for the longer-run, they are more likely to be saved $^{2}$.

The idea that less regular income is more likely to be saved is further supported by the precautionary saving motive (Leland 1968). When households find it more difficult to predict future income flows, they tend to save more -as a precaution against future income shortfalls. The LCPIH and precautionary saving motives lead us to suggest that remittance-receiving households with more volatile remittance inflows will save more by engaging in more asset accumulation ${ }^{3}$.

Concern about the economic and social implications of remittances in the receiving countries has permeated much of the debate on remittances. Gaining a better understanding about the impact of remittances on asset accumulation in remittance-receiving households can further inform on the economic well-being of migrant-sending nations. Despite the overall optimism concerning the important and positive role that remittances play in poorer countries, there are a number of studies that point to unfavorable effects, such as reducing labor supply, depressing long-run economic growth and breeding "dependency" (see Keely and Tran 1989, Glytsos 1993, Durand et al. 1996, Adams 2011, Senbeta 2013).

While we do not subscribe to the view that expenditures on consumption are undesirable (they can significantly raise the quality of life of recipient households), we do see an important role for investment in human, physical and financial assets as they facilitate entrepreneurial investments and the accumulation of back-up savings for consumption-smoothing over the lifecycle. Consequently, a better understanding of the factors influencing the channeling of remittances by households towards the accumulation of human, financial and physical assets can inform on policies that may help harness the most out of remittance inflows.

\section{Data}

We use data from the more recent and harmonized 2000, 2002, 2004, 2005, 2006, 2008, 2010 and 2012 waves of the Mexican Encuesta Nacional de Ingresos y Gastos de los Hogares (ENIGH), a nationally representative survey carried out by the Mexican Statistical Institute (Instituto Nacional de Estadística, Geografía e Informática - INEGI at http://www.inegi.gob.mx) with the purpose of providing information on the size, structure, and distribution of Mexican households' income and expenditures. The survey was first administered in 1983-1984. The ENIGH is designed to be representative at the (a) national, (b) urban (localities with 2,500 inhabitants or more), and (c) rural (localities with less than 2,500 inhabitants) levels via appropriate household level weighting. Its population coverage includes national and foreign households living in 
private dwellings in Mexico. The sampling frame is the one used by the INEGI for multiple purposes and is derived from demographic and geographic information obtained from the national censuses.

The ENIGH covers all household expenditures, including expenditures on education, health, durable assets, micro-enterprise investments, financial asset accumulation, real estate, food, transportation and personal care expenditures. All of the variables used in this article and their definitions can be found in Appendix Table 8. Our approach is to group these expenditures into two categories, which we label as "ordinary consumption" and "asset accumulation." We define asset accumulation in a broad sense to include spending on the accumulation of human capital (education and health), physical assets (durable assets plus businesses and micro-enterprises plus real estate assets), and financial capital (the sum of bank deposits, loans to others, stocks, bonds, and other financial market investment instruments). Our definition of "asset accumulation" is intended to get at saving. While this approach to measuring saving may appear unusual, in a country like Mexico, much of the population has limited avenues for accumulating financial assets owing to their unbanked status, mistrust of financial institutions and relative shallowness of the financial system. This is especially true among rural households, a population of primary interest in the analysis of remittances as they receive most of Mexico's remittance inflows. Therefore, the purchase of durable assets ${ }^{4}$, spending on human capital, and improvements in existing housing structures can account for much of the household's asset accumulation ${ }^{5}$.

In addition to detailed data on expenditures, the ENIGH contains information on general socio-demographic and economic characteristics of all household members ${ }^{6}$. Of particular interest to us is the thorough information on all income received by the household in each of the past six months. The detailed six-month income history is indeed unique to the ENIGH and allows us to learn about the impact of the volatility in remittance inflows (over the past 6 months) on the household's share of expenditures on asset accumulation in the prior quarter ${ }^{7}$. By asking respondents about their receipt of remittances in each of the six months prior to the interview, we are able to construct a measure of the volatility of this time series of income inflows and use it as a proxy for remittance income uncertainty.

Our measure of remittance income volatility is the coefficient of variation ${ }^{8}$, which is computed as the standard deviation of inflows for the household over the six-month period divided by the average monthly inflow ${ }^{9}$. There are several advantages to using the coefficient of variation. First, it is unit-less or scale invariant. This allows us to measure the volatility of receipts regardless of their overall dollar amounts. Second, it is a straight-forward statistic to compute. One could, however, argue that it captures expected plus unexpected volatility in remittance receipts. Therefore, it does not entirely fit with the theory, which suggests that uncertainty or unexpected volatility is what really drives saving behavior. Nonetheless, without additional information -such as respondents' own assessment of the uncertainty surrounding future remittance receipts or a much longer time series of receipts from which a more sophisticated model of uncertainty can be derived, it is not feasible to construct a variable that exclusively measures the uncertainty in remittance receipts. Therefore, we use the volatility of remittance receipts, derived from the respondent's recollection of the series, as a proxy for the (perceived) uncertainty of future remittance inflows. 
Before proceeding any further, it is important to note some limitations of our data, such as the fact that we only have information on remittance receipts over the past six months. In some instances, households may be receiving remittances only once a year. If that happens to be during the six months for which we lack data of remittance receipts, we will be categorizing these households as non-recipients. This is a problem that exists for any dataset with information on remittances. For example, the 2010 Mexican census asked households about their remittance receipts only over the past month. Consequently, any study that estimates the impact of remittances on Mexican households using the census will suffer from the same bias, as there will be a group of household who did not receive remittances in the previous month, but did in prior months. Despite the possibility of misclassifying some households as non-recipients when, in fact, they are not, the bias due to this omission is likely to be small given what we know about the time pattern of remittances. In other surveys of remittances, very few remitters claim to remit at frequencies lower than twice a year ${ }^{10}$. Nevertheless, as we shall note in what follows, we also use instrumental variable methods to address this measurement error bias.

\section{Some descriptive evidence}

Table 1 provides a brief description of households in our initial sample. There are approximately 160,000 households, of which over 22 percent are female-headed. The average household has 4 members, of whom 0.55 are children six years of age or younger (i.e. about 14 percent of household members) and 0.26 individuals are adults 65 years of age and older (i.e. about 6.5 percent of household members). Approximately half the members in a typical household have low educational attainment. An additional 1.3 individuals (or 33 percent of household members) have a middle school education. On average, only 0.5 individuals or 13 percent of household members have a high school degree or a higher level of educational attainment. Finally, about 1.7 individuals or 43 percent of household members are working and, geographically, a little more than a quarter of total households are located in rural areas (defined as areas with less than 2,500 inhabitants).

What can we say about the spending patterns of households in our sample? Table 2 reports on the percentage of households with expenditures in the different categories of interest $\mathrm{t}^{11}$. By far, after ordinary consumption expenditures, health expenditures are

Table 1 Household level descriptive statistics

\begin{tabular}{lccccc}
\hline Variables & Observations & Mean & S.D. & Min & Max \\
\hline Female headed household & 159,940 & 0.222 & 0.416 & 0 & 1 \\
Household Size & 159,940 & 4.020 & 2.025 & 1 & 43 \\
Number of young children in HH & 159,940 & 0.554 & 0.833 & 0 & 10 \\
Number of elderly members in HH & 159,940 & 0.260 & 0.566 & 0 & 5 \\
Number of HH members with primary education or less & 159,940 & 2.044 & 1.767 & 0 & 22 \\
Number of HH members with middle school & 159,940 & 1.282 & 1.260 & 0 & 24 \\
Number of HH members with high school or more & 159,940 & 0.486 & 0.870 & 0 & 9 \\
Number of HH members employed & 159,940 & 1.683 & 1.154 & 0 & 16 \\
Lives in a Rural Area & 159,940 & 0.260 & 0.439 & 0 & 1 \\
\hline
\end{tabular}


Table 2 Average household expenditures over the past quarter

\begin{tabular}{lcc}
\hline Variables & $\begin{array}{c}\text { Percent of HH } \\
\text { reporting this } \\
\text { expenditure }\end{array}$ & $\begin{array}{c}\text { Average peso } \\
\text { expenditure } \\
\text { if reported }\end{array}$ \\
\hline $\begin{array}{l}\text { Human capital investments } \\
\quad \begin{array}{l}\text { Educational investments } \\
\quad \text { Health investments }\end{array}\end{array}$ & 58 & 2,314 \\
Physical investments & 15 & 835 \\
$\quad$ Real estate investments (e.g. housing, land, etc.) & 2 & 3,419 \\
$\quad$ Business investments (e.g. micro-enterprises) & 23 & 3,882 \\
$\quad$ Purchase of durable assets & & 628 \\
Financial investments & 28 & 5,338 \\
$\quad$ Financial investments (e.g. bank deposits, stock, etc.) & 100 & 20,126 \\
Ordinary expenditures (e.g. food, clothing, transportation, etc.) & 100 & 23,082 \\
Total average spending &
\end{tabular}

the most common expenditures with 59 percent of households spending in this category during the past quarter. Table 2 also reports on the last quarter's average expenditure in each of the categories of interest conditional on spending in that category. After ordinary consumption expenditures, the largest household expenditure is on financial investments. Conditional on spending on financial assets, the average expenditure in this category amounts to approximately 5,338 pesos during the past quarter. To complement these figures, we also display the density plots of the shares of spending on asset accumulation, as opposed to spending on ordinary expenditures, in Figures 1 and 2. All levels of expenditure are represented in the plots, with most households spending relatively large shares on ordinary expenditures and relatively small shares on asset accumulation.

What are the remittance receiving patterns of households in our sample? Table 3 addresses this question. Almost 6 percent of the approximately 160,000 households in

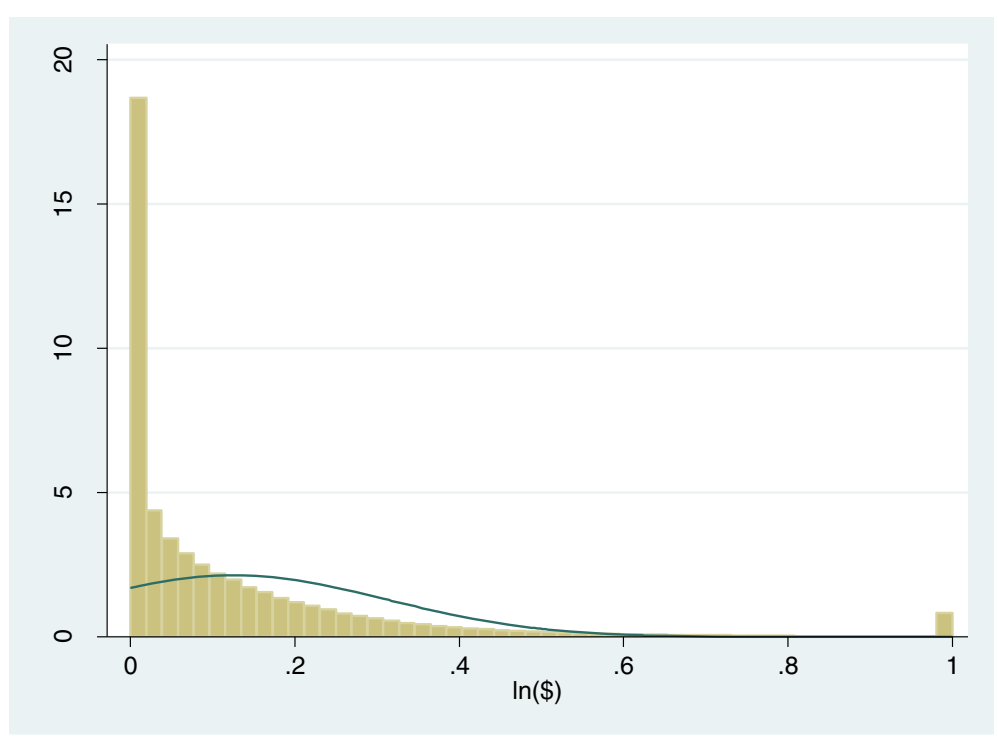

Figure 1 Density of the share of spending on asset accumulation. 


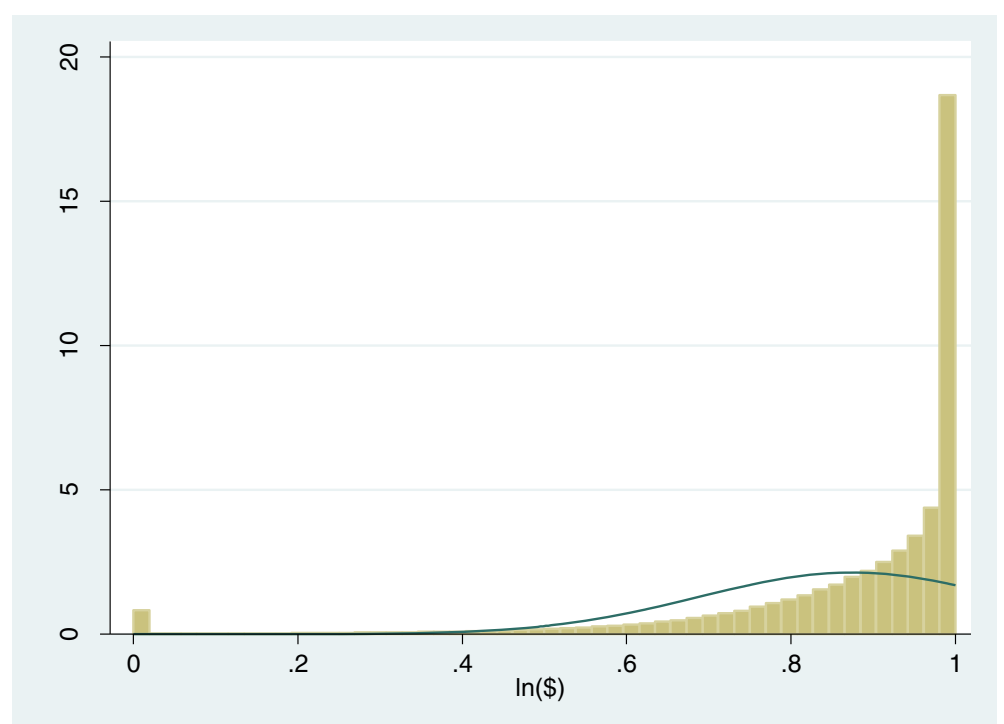

Figure 2 Density of the share of spending on ordinary expenditures.

our sample receive remittances. Slightly more than half of these households (3.3 percent of all households in the sample) receive remittances each month. The other remittance-receiving households receive international transfers on a more irregular basis. How large are these remittance inflows? Conditional on residing in a remittancereceiving household (i.e. for 9,441 households), total household remittance receipts average 10,866 pesos over a six-month period (approximately 1,811 pesos or 161 U.S. dollars per month) ${ }^{12}$. These figures compare to 40,778 pesos of income (excluding remittances) over a six-month period (i.e. 6,796 pesos or 605 U.S. dollars per month). Therefore, remittances (on average) account for about 21 percent of household income in remittance-receiving households and, as such, have the potential to significantly impact their expenditure patterns.

Do remittance-receiving households display a different spending pattern than their non-remittance receiving counterparts? And, if they do, does the volatility of remittance income affect how much they spend on human, physical and financial assets? Table 4 and Table 5 provide some insight into these questions. At a mere descriptive level, the share of spending on human, physical and financial assets for remittancereceiving households is 14.5 percent, that is 2.1 percentage points more than for nonremittance receiving households (see Table 4). Such a finding is consistent with the notion that increases in remittances are spent differently than increases in ordinary income. As we distinguish by expenditure category, remittance-receiving households

Table 3 Remittance and other income descriptive statistics over the past six months

\begin{tabular}{lccc}
\hline Variables & Observations & Mean & S.D. \\
\hline Remittance receiving household & 159,940 & 0.059 & 0.236 \\
Households receiving remittance each month & 159,940 & 0.033 & 0.180 \\
Households receiving remittances 1 to 5 times in six months & 159,940 & 0.026 & 0.158 \\
Household remittance income (pesos) (six-months) & 9,441 & 10,866 & 12,365 \\
Household income excluding remittances (pesos) (six-months) & 159,940 & 40,778 & 67,790 \\
\hline
\end{tabular}




\begin{tabular}{|c|c|c|c|c|}
\hline Type of expenditure & $\mathbf{N}$ & Share of $\mathrm{HH}$ expenditures & Difference & t-statistic \\
\hline \multicolumn{5}{|l|}{ Overall asset accumulation } \\
\hline Receiving remittances & 9,441 & 0.145 & & \\
\hline Not receiving remittances & 150,499 & 0.124 & $0.020^{* * *}$ & 9.78 \\
\hline \multicolumn{5}{|l|}{ Educational investments } \\
\hline Receiving remittances & 9,441 & 0.028 & & \\
\hline Not receiving remittances & 150,499 & 0.036 & $-0.008^{* *}$ & -11.34 \\
\hline \multicolumn{5}{|l|}{ Health investments } \\
\hline Receiving remittances & 9,441 & 0.036 & & \\
\hline Not receiving remittances & 150,499 & 0.027 & $0.010^{* * *}$ & 8.07 \\
\hline \multicolumn{5}{|l|}{ Purchase of durable assets } \\
\hline Receiving remittances & 9,441 & $7.3 e-03$ & & \\
\hline Not receiving remittances & 150,499 & $6.6 \mathrm{e}-03$ & $0.001^{* *}$ & 2.16 \\
\hline \multicolumn{5}{|l|}{ Real estate investments } \\
\hline Receiving remittances & 9,441 & 0.021 & & \\
\hline Not receiving remittances & 150,499 & 0.019 & 0.001 & 0.59 \\
\hline \multicolumn{5}{|l|}{ Financial investments } \\
\hline Receiving remittances & 9,441 & 0.088 & & \\
\hline Not receiving remittances & 150,499 & 0.066 & $0.021^{* *}$ & 1.96 \\
\hline \multicolumn{5}{|l|}{ Business investments } \\
\hline Receiving remittances & 9,441 & 0.004 & & \\
\hline Not receiving remittances & 150,499 & 0.003 & $0.001^{*}$ & 1.86 \\
\hline \multicolumn{5}{|l|}{ Ordinary expenditures } \\
\hline Receiving remittances & 9,441 & 0.856 & & \\
\hline Not receiving remittances & 150,499 & 0.876 & $-0.020^{* * *}$ & -9.78 \\
\hline
\end{tabular}

Notes: The null hypothesis is: $\mathrm{H}_{0}$ : diff $=0$ and the alternative hypothesis is given by $\mathrm{H}_{\mathrm{a}}$ : diff $<0$. ${ }^{* *}$ Significant at the 1 percent level or better, **significant at 5 percent level or better.

appear to spend a greater share on health, durable assets, financial and business assets. In each case, the difference in the share of spending is statistically significant at the 5 percent level or better. The results for Table 4 indicate that remittance-receiving households appear to spend less on education when compared to their non-remittance receiving counterparts. This finding could support Kandel and Kao's (2001) finding that investments on children's education in Mexican households are lower for households with emigrant family members. Given that Mexican education is not valued in the U.S., there may exist less of an incentive to invest in education for these households if they expect to migrate to the U.S. Alternatively, the difference in educational expenditures may be a by-product of differences in household demographics of recipient and nonrecipient households. Finally, the descriptive statistics also indicate that households receiving remittances spend a greater share on real estate-but the difference is not statistically significant.

To gain further insights into the impacts of remittance inflows on household spending patterns we now turn to examining remittance-receiving households exclusively. Table 5 reports expenditure shares on asset accumulation according to the uncertainty of remittance inflows. We separate households into two categories. The first category 
Table 5 Share of household expenditures over the past quarter according to remittance income uncertainty

\begin{tabular}{|c|c|c|c|c|}
\hline Type of expenditure & $\mathrm{N}$ & Share of HH expenditures & Difference & t-statistic \\
\hline \multicolumn{5}{|c|}{ Overall asset accumulation } \\
\hline High uncertainty & 4,718 & 0.153 & & \\
\hline Low uncertainty & 4,723 & 0.136 & $0.017^{* * *}$ & 4.11 \\
\hline \multicolumn{5}{|l|}{ Educational investments } \\
\hline High uncertainty & 4,718 & 0.026 & & \\
\hline Low uncertainty & 4,723 & 0.029 & $-0.003^{* *}$ & -2.08 \\
\hline \multicolumn{5}{|l|}{ Health investments } \\
\hline High uncertainty & 4,718 & 0.040 & & \\
\hline Low uncertainty & 4,723 & 0.032 & $0.008^{* * *}$ & 3.42 \\
\hline \multicolumn{5}{|c|}{ Purchase of durable assets } \\
\hline High uncertainty & 4,718 & 0.008 & & \\
\hline Low uncertainty & 4,723 & 0.007 & 0.001 & 1.03 \\
\hline \multicolumn{5}{|l|}{ Real estate investments } \\
\hline High uncertainty & 4,718 & 0.026 & & \\
\hline Low uncertainty & 4,723 & 0.016 & $0.010^{* * *}$ & 3.10 \\
\hline \multicolumn{5}{|l|}{ Financial investments } \\
\hline High uncertainty & 4,718 & 0.085 & & \\
\hline Low uncertainty & 4,723 & 0.089 & 0.004 & 0.20 \\
\hline \multicolumn{5}{|l|}{ Business investments } \\
\hline High uncertainty & 4,718 & 0.005 & & \\
\hline Low uncertainty & 4,723 & 0.004 & 0.001 & 0.8496 \\
\hline \multicolumn{5}{|l|}{ Ordinary expenditures } \\
\hline High uncertainty & 4,718 & 0.847 & & \\
\hline Low uncertainty & 4,723 & 0.863 & $-0.017^{* * *}$ & -4.11 \\
\hline
\end{tabular}

Notes: The null hypothesis is: $\mathrm{H}_{0}$ : diff $=0$ and the alternative hypothesis is given by $\mathrm{H}_{\mathrm{a}}$ : diff $<0$. ${ }^{* *}$ Significant at the 1 percent level or better, ${ }^{* *}$ significant at 5 percent level or better.

consists of remittance-receiving households enduring high uncertainty in their remittance inflows as reflected by a high level of variability in remittance income, which, in turn, is captured by the coefficient of variation of remittance income falling in the upper two quartiles of the distribution. The second category is composed of remittance-receiving households with less volatile remittance inflows as reflected by a coefficient of variation for remittance income that falls within the lower two quartiles of the distribution. The results indicate that higher uncertainty in the receipt of remittance inflows favors asset accumulation by approximately 2 additional percentage points. By asset category, more volatile remittance income results in a statistically higher share of asset accumulation in health and in real estate and a lower share with respect to spending on education. For durable assets and for business investments, there appears to be no differences in spending by uncertainty levels. Yet, these figures do not take into account other household characteristics possibly correlated with their spending and remittance-receiving patterns, such as the level or magnitude of their remittance receipts. We address this limitation in the next sections in order to more fully understand how uncertainty in remittance receipts affects asset accumulation. 


\section{Methods}

Our purpose is to examine the role that the uncertainty of remittance income has on the spending patterns of remittance-receiving households and, in particular, on their human, physical and financial asset accumulation patterns once we account for the dollar amount received. To this end, we start by first estimating the following benchmark model:

$$
A A_{i}^{*}=\alpha_{0}+\alpha_{1} R_{i}+\alpha_{2} R V_{i}+X_{i}^{A A} \theta^{A A}+\gamma_{s}+\delta_{t}+\gamma_{s} t+\varepsilon_{i}^{A A}
$$

where: $\varepsilon_{i}^{A A} \sim N\left(0, \sigma^{2}\right)$ and $A A_{i}=\max \left(0, A A_{i}^{*}\right)$ for $i=1, \ldots, n$ individuals. Our dependent variable, $A A$, measures the share of spending on asset accumulation (whether human, physical or financial assets) over the past quarter. $R$ captures the magnitude or level of remittance inflows during the past six-months and $R V$ is our measure of remittanceincome volatility over the same time period ${ }^{13}$. The vector $X^{A A}$ controls for household variables likely impacting asset accumulation, including household size, household composition $^{14}$, household educational attainment and employment, household location in an urban or rural area, as well as information on the level and uncertainty of other sources of household income ${ }^{15}$. Finally, a battery of state fixed-effects, year fixed-effects and state-level time trends are also included to help capture regional and macroeconomic factors affecting asset accumulation (e.g. well-established migration networks in specific states, economy-wide shocks or business cycles), as well as time-varying economic conditions at the state level.

A few econometric issues arise in the estimation of Equation (1). One of the problems refers to the potential correlation between remittance income and remittance income uncertainty with the error term in Equation (1). As such, both regressors may be endogenous and their coefficient estimates biased. In particular, unobserved heterogeneity and omitted variable bias may exist if remittance income and its uncertainty are related to unobserved household characteristics which, in turn, influence how much the household chooses to spend on asset accumulation ${ }^{16}$. Additionally, there is the potential of reverse causality as household expenditure patterns may influence emigrants' decision to send remittances home as well as the pattern with which they make such transfers. Finally, remittance income and its uncertainty may be subject to the classical errors-in-variables (CEV) problem as a result of the six-month time period for which we have information on remittance receipts. The CEV problem is likely to cause an attenuation bias, thus underestimating the impact of remittance income and its uncertainty on the spending patterns of remittance-receiving households (Wooldridge 2009). Although we do not expect large measurement problems based on the remitting patterns reported in other surveys ${ }^{17}$, we acknowledge this possibility and make use of instrumental variables to address it.

\section{A). Modeling remittance income and remittance income volatility}

We address the endogeneity of remittance income and remittance income volatility, along with the potential CEV problems in measuring remittance income and remittance income volatility, using an instrumental variable approach. We instrument remittance income and remittance income volatility with the predicted values derived from models of remittance flows and remittance income volatility. Because only 6 percent of individuals reside in a remittance-receiving household, the distribution that applies to 
the modeling of remittance inflows and remittance income volatility is both discrete and continuous. An option in those instances is to use selection models (such as the Heckman-type model). However, the results from such models are sensitive to identification exclusions that are debatable given the difficulty of envisioning factors that affect the likelihood of remittance receipt or that of experiencing remittance income volatility, yet have no impact on the peso amount received by the household or on the degree of remittance income volatility endured.

An alternative that allows us to circumvent that identification problem is the Tobit model (Brown 1997, Ravallion and Dearden 1998, Schrieder and Knerr 2000). Therefore, we predict remittance income and remittance income volatility using a Tobit specification where remittances and the volatility surrounding remittance levels are determined as follows:

$$
\begin{aligned}
& R_{i}^{*}=\beta_{0}+X_{i}^{R} \theta^{R}+\gamma_{s}+\delta_{t}+\gamma_{s} t+\varepsilon_{i}^{R}, \quad \varepsilon_{i}^{R} \sim N\left(0, \sigma^{2}\right), \quad R_{i}=\max \left(0, R_{i}^{*}\right) \\
& R V_{i}^{*}=X_{0}+X_{i}^{R V} \theta^{R V}+\gamma_{s}+\delta_{t}+\gamma_{s} t+\varepsilon_{i}^{R V}, \quad \varepsilon_{i}^{R V} \sim N\left(0, \sigma^{2}\right), \quad R V_{i}=\max \left(0, R V_{i}^{*}\right)
\end{aligned}
$$

Just as Equation (1) does for asset accumulation, Equations (2) and (3) include a battery of state fixed-effects, year fixed-effects and state-level time trends capturing regional and macroeconomic factors affecting remittance flows (e.g. well-established migration networks in poorer states, economy-wide shocks or business cycles), and time-varying economic conditions at the state level. Similarly, the vectors $X^{R}$ and $X^{R V}$ incorporate the same household and individual level variables traditionally included when modeling asset accumulation -factors also likely to determine remittances levels and volatility. However, for identification purposes, the vectors $X^{R}$ and $X^{R V}$ also include information on two instrumental variables: unemployment rate volatility and wage volatility in U.S. states that are the likely destinations of Mexican emigrants. The rationale for our choice of instruments is the expectation that volatility in unemployment and wages in U.S. destinations for Mexican emigrants are likely to be highly correlated to their earnings in the United States and, in turn, to the pattern of their remittance outflows. Common U.S. state destinations for Mexican emigrants are obtained for each Mexican state in our sample from the Mexican Migration Project database. The volatility in U.S. unemployment and wage rates are then constructed and used as instruments for the level and volatility of remittance flows received by households in the various Mexican states and survey years included in the analysis ${ }^{18}$. While the two instruments are highly correlated to the level and volatility in remittance income, in order to constitute valid instruments, they also need to be uncorrelated to the error term in the main regression ${ }^{19}$. Our identifying assumption is that U.S. labor market conditions over the past six-months do not affect asset accumulation patterns in Mexico other than via migration and remittance inflows. Nonetheless, we foresee some shortcomings in our choice of instruments that we now refer to and address in the analysis.

First, our instruments could be correlated to unobserved household characteristics possibly impacting the asset accumulation patterns of family members left behind, such as household wealth ${ }^{20}$. Better-to-do households may have been historically more likely to place migrants in U.S. states with lower unemployment and wage volatility. To address this concern, we include information on the educational attainment and 
employment of household members in Mexico, as well as on the level of non-labor income (all highly correlated to household wealth).

A second possible threat to the validity of our instruments is that, owing to the close ties between the Mexican and U.S. economies, unemployment rates and wages in destination states in the United States may be correlated to Mexican economic conditions impacting the asset accumulation and, overall, investment patterns of Mexicans. To address this possibility, we have included Mexican state and year fixed-effects, along with Mexican state-level time trends. The latter help account for state-specific characteristics, as well as for economy-wide and time-varying economic conditions at the state level.

A third concern with our instruments is that they could be related to Mexican migration. As noted earlier, year-fixed effects, state-level fixed-effects and state-level time trends should be capturing aggregate changes in migration patterns. One might still worry about changes at the household level. Better employment or wage prospects in the United States during much of the time period under examination may have induced the emigration of some household members and possibly favored (through the receipt of remittances) the asset accumulation patterns of individuals responding to the survey. Alternatively, poor employment conditions in the United States after 2008 may have induced return migration and reduced the asset accumulation of individual household members measured by the survey. We lack information on emigration at the household level; nevertheless, we control for household size and household composition $^{21}$.

Summing up, unemployment volatility and wage volatility in U.S. states that are the likely destinations of Mexican emigrants perform well and, given the controls included, appear to be reasonable instruments for remittance inflows received by Mexican households.

\section{B). Modeling asset accumulation}

In order to model household asset accumulation patterns, we estimate Equations (2) and (3) and derive predicted values for remittance inflows $\left(\bar{R}_{i}\right)$ and remittance income volatility $\left(\overline{R V}_{i}\right)$ to be used in the modeling of asset accumulation decisions. As such, Equation (1) becomes:

$$
A A_{i}^{*}=\alpha_{0}+\alpha_{1} \bar{R}_{i}+\alpha_{2} \overline{R V}_{i}+X_{i}^{A A} \theta^{A A}+\gamma_{s}+\delta_{t}+\gamma_{s} t+\varepsilon_{i}^{A A}
$$

where the $\bar{R}_{i}$ and $\overline{R V}_{i}$ are set equal to the predicted values of remittance income and remittance income volatility resulting from the estimation of the Tobit models described by Equations (2) and (3). As in the case of remittance income, we are confronted with the fact that $A A$ is equal to zero for a non-negligible share of individuals in the sample. Furthermore, the dependent variable is highly skewed (approximately log-normally distributed) and heteroscedastic ${ }^{22,23}$. Using a Tobit model to estimate Equation (4) would be inappropriate for a number of reasons, including the fact that the Tobit relies crucially on normality and homoscedasticity in the underlying latent variable model. As noted by Wooldridge (2009), an alternative to using a Tobit model (and avoiding the problem of identification in a traditional Heckman model) is to estimate a two-part model $^{24}$. Therefore, we opt for a simple two-part model where the 
initial likelihood of accumulating assets is separated from the process determining how much is accumulated. In the first part of the model, we estimate the likelihood of accumulating assets for each household in the sample via a probit model as follows:

$$
\begin{aligned}
& P\left(A A_{i}=0 \mid \bar{R}_{i}, \overline{R V}_{i}, X_{i}^{A A}, \gamma_{s}, \delta_{t}, \gamma_{s} t\right)= \\
& \quad 1-\Phi\left(\alpha_{0,1}+\alpha_{1,1} \bar{R}_{i}+\alpha_{2,1} \overline{R V}_{i}+X_{i}^{A A} \theta_{2,1}^{A A}+\gamma_{s}+\delta_{t}+\gamma_{s} t\right)
\end{aligned}
$$

where: $\varepsilon_{i, 1}^{A A} \sim N(0,1)$. Subsequently, in the second part of the model, we model the share of spending on asset accumulation (whether human, physical or financial assets) over the past quarter for households engaged in such a practice as follows:

$$
\log \left(A A_{i} \mid A A_{i}>0\right)=\alpha_{0,2}+\alpha_{1,2} \bar{R}_{i}+\alpha_{2,2} \overline{R V}_{i}+X_{i}^{A A} \theta_{2,2}^{A A}+\gamma_{s}+\delta_{t}+\gamma_{s} t+\varepsilon_{i, 2}^{A A}
$$

where: $\varepsilon_{i, 2}^{A A} \sim \operatorname{Normal}\left(0, \sigma^{2}\right)$. Equations (5) and (6) can be estimated separately by maximum likelihood. As in the estimation of Equations (2) and (3), standard errors are clustered at the Mexican state level and robust standard errors are computed for inference purposes.

\section{Findings}

Our primary aim is to ascertain the impact of remittance income uncertainty on the asset accumulation patterns of remittance-receiving households once we take into account the magnitude of their remittance inflows. Does it matter if remittances are forthcoming on a regular basis? Do households adjust their asset accumulation patterns to the certainty with which they receive inflows from abroad? Table 6 sheds some light on these questions by displaying the results from a two-part model of the fraction of total household expenditures on asset (human, physical or financial) purchases by households. A couple of facts regarding our model specification are worth noting before proceeding any further. First, our dependent variable refers to last quarter's household expenditure on human, physical and financial assets (as a share of total household expenditures). Specifically, the numerator incorporates household expenditures on education, health, durable assets, real estate, business investments and financial assetsmeant to capture total asset accumulation or contributions toward saving 25 . Second, in addition to accounting for the level of remittance income inflows, we control for the level of household income (excluding remittances) and its uncertainty as additional determinants of household spending patterns. Their estimated coefficients may serve as reference when gauging the magnitude of the estimated impacts of remittance levels and volatility on the household's asset accumulation patterns. However, recognizing the potential endogeneity of the level and volatility of other sources of household income, we re-estimate the models excluding those two regressors. Our key findings, which are displayed in Tables 9 and 10 in the Appendix, remain robust to the use of that alternative specification. Therefore, in what follows, we focus our discussion on the most complete model.

What are the key findings from Table 6? First, remittances, just as other household income, promote asset accumulation. A 1,000 peso increase (about USD 100) in remittance income over the past six months raises the likelihood of engaging in asset accumulation by three-tenths of a percentage point and the share of household expenditures in this category by one percent ${ }^{26}$. To put these values into perspective, 
Table 6 Two part model for share of households' expenditures on human, physical and financial assets

\begin{tabular}{|c|c|c|c|c|c|c|}
\hline \multirow[t]{2}{*}{ Variables } & \multicolumn{4}{|c|}{ First part } & \multicolumn{2}{|c|}{ Second part } \\
\hline & Coefficient & $\begin{array}{l}\text { Robust } \\
\text { S.E. }\end{array}$ & $\begin{array}{c}\text { M.E. on } \\
\text { Prob }(Y>0)\end{array}$ & $\begin{array}{l}\text { Robust } \\
\text { S.E. }\end{array}$ & $\begin{array}{l}\text { Coefficient/M.E. } \\
\text { on } E(Y \mid Y>0)\end{array}$ & $\begin{array}{l}\text { Robust } \\
\text { S.E. }\end{array}$ \\
\hline $\begin{array}{l}\text { HH remittance income } \\
(1,000 \text { pesos) }\end{array}$ & $0.011^{* * *}$ & 0.001 & $0.003^{* * *}$ & $3.1 \mathrm{E}-04$ & $0.010^{* * *}$ & 0.001 \\
\hline Remittance income volatility & $0.085^{* * *}$ & 0.015 & $0.020^{* * *}$ & 0.004 & $0.047^{* * *}$ & 0.017 \\
\hline Female headed $\mathrm{HH}$ & -0.015 & 0.010 & -0.003 & 0.002 & 0.000 & 0.012 \\
\hline $\begin{array}{l}\text { Number of young children } \\
\text { in the } \mathrm{HH}\end{array}$ & 0.010 & 0.006 & 0.002 & 0.002 & $-0.032^{* * *}$ & 0.006 \\
\hline Number of elderly HH members & $-0.099^{* * *}$ & 0.007 & $-0.023^{* * *}$ & 0.002 & $-0.029^{* * *}$ & 0.007 \\
\hline $\begin{array}{l}\text { Number of } \mathrm{HH} \text { members with } \\
\text { high school or above }\end{array}$ & $0.104^{* * *}$ & 0.006 & $0.025^{* * *}$ & 0.001 & -0.022 & 0.019 \\
\hline $\begin{array}{l}\text { Number of } \mathrm{HH} \text { members with } \\
\text { middle school }\end{array}$ & $0.071^{* * *}$ & 0.004 & $0.017^{* * *}$ & 0.001 & 0.013 & 0.008 \\
\hline Number of HH members employed & $-0.012^{* * *}$ & 0.005 & $-0.003^{* * *}$ & 0.001 & $-0.036^{* * *}$ & 0.007 \\
\hline $\begin{array}{l}\text { HH Income excluding remittances } \\
\text { (in 1,000 pesos) }\end{array}$ & $0.002^{* * *}$ & $1.5 \mathrm{E}-04$ & $0.001^{* * *}$ & 4.0E-05 & $0.001^{* * *}$ & $1.9 \mathrm{E}-04$ \\
\hline $\begin{array}{l}\text { Uncertainty of HH income } \\
\text { excluding remittances }\end{array}$ & 0.008 & 0.011 & 0.002 & 0.003 & $0.120^{* * *}$ & 0.030 \\
\hline Household size & $0.051^{* * *}$ & 0.003 & $0.012^{* * *}$ & 0.001 & $0.032^{* * *}$ & 0.005 \\
\hline Rural household & $-0.121^{* * *}$ & 0.010 & $-0.029^{* * *}$ & 0.003 & $0.088^{* * *}$ & 0.024 \\
\hline Year fixed-effects & \multicolumn{4}{|c|}{ Yes } & \multicolumn{2}{|l|}{ Yes } \\
\hline Mexican state fixed-effects & \multicolumn{4}{|c|}{ Yes } & \multicolumn{2}{|l|}{ Yes } \\
\hline Mexican state-level time trends & \multicolumn{4}{|c|}{ Yes } & \multicolumn{2}{|l|}{ Yes } \\
\hline Observations: & \multicolumn{4}{|c|}{159,523} & \multicolumn{2}{|l|}{125,992} \\
\hline Significance & \multicolumn{4}{|c|}{$\begin{array}{c}\text { Wald Chi2 }=31,481.19 \\
\text { with Prob }>\text { Chi2 }=0.000\end{array}$} & \multicolumn{2}{|c|}{ R-squared $=0.112$} \\
\hline
\end{tabular}

Notes: ***Significant at the 1 percent level or better. All regressions include a constant term. Standard errors are clustered at the Mexican state level. Marginal effects are evaluated at the mean.

suppose that remittance inflows were to increase by USD 50 (or 500 pesos) per month. In that case, the USD 300 (or 3,000 peso) increase in remittances over a six-month period would raise the likelihood of asset accumulation by approximately 1 percentage point and the share of household expenditures in asset accumulation by 3 percent. These values are substantially larger than the ones found for similar increments in non-remittance income, for which a similar 3,000 peso increment would raise the likelihood of engaging in asset accumulation by three-tenths of a percentage point and the saving rate by 0.3 percent.

Secondly, the certainty with which remittances are received also affects household spending shares on human, physical and financial assets. As hypothesized earlier, households with more variable remittance inflows -as captured by the coefficient of variation of household remittance income- have larger expenditure shares on human, physical and financial assets. A one standard deviation increase in the uncertainty of remittance income raises the likelihood of asset accumulation by approximately 1.8 percentage points $\left(0.89^{*} 0.02\right)$ and the share of household expenditures in this category by 4.2 percent $(0.89 * 0.047)^{27}$. We also find that spending on human, physical and financial assets by Mexican households appears sensitive to fluctuations in the uncertainty of 
non-remittance income. While an increase (one standard deviation) in the uncertainty of other sources of household income does not alter the likelihood that the household will engage in asset accumulation, the expenditure share is increased by about 7 percent $(0.12 \% 0.57)$ among households already accumulating assets ${ }^{28}$.

Other findings from Table 6 include the fact that, while the incidence of engaging in asset accumulation is higher in households with more educated household members, the share of household expenditures on asset accumulation does not seem to be significantly impacted by educational attainment. We also find that asset accumulation is inversely related to the number of employed household members -a finding likely to be driven by the fact that individuals in wealthier households are less likely to be at work (owing to their higher reservation wages). Yet, wealthier households are also the ones engaging in greater asset accumulation. Hence, asset accumulation is inversely related to the number of employed household members. Finally, while the incidence of asset accumulation appears lower among rural households, their share of spending on asset accumulation is higher than among urban households.

The estimates in Table 6 assume that the level and uncertainty of remittance income inflows are exogenous. However, as discussed earlier on, one can easily argue otherwise. Hence, in Table 7, we address the potential endogeneity of the level and uncertainty of remittance income inflows by estimating a Tobit model for remittances using instrumental variable methods. As noted earlier, we instrument the level and uncertainty of remittance income inflows using two instruments that gather information on the economic conditions in the U.S. states from where remittances are likely to originate: the volatility in unemployment rates and the volatility in wages in those U.S. destination states $^{29}$.

We inspect our instrumental variables to ascertain their validity from an econometric standpoint. We first confirm that they are jointly significant in explaining remittance income and its uncertainty - the endogenous regressors being instrumented. The estimation results displayed in Table 11 in the Appendix suggest they are. In order to constitute valid instruments, the two instruments need to be highly correlated to the endogenous regressors being instrumented and uncorrelated to the error term in the main regression. While we cannot formally test the latter, the two instruments appear to be highly correlated to the level and volatility in remittance income. Specifically, higher unemployment and wage volatility in U.S. states from where remittances more likely originate, contribute toward lower remittance receipts. This is expected to be the case if both weaken immigrants' ability to remit by imposing liquidity constraints. Additionally, higher unemployment and wage volatility in the United States reduce remittance income volatility. This finding suggests that when labor market conditions in the United States become less predictable, migrants may be more likely to send money home on a regular basis as a self-insurance mechanism, thus making the stream of flows to Mexico less volatile.

Once we address the endogeneity of our key regressors, do the level and the uncertainty of remittance income continue to significantly shape household asset accumulation patterns? According to the figures in Table 7, the answer is yes. A 1,000 peso increase in remittance income raises the likelihood of asset accumulation by approximately a third of a percentage points, even though it does not seem to significantly impact the household's share of expenditures on this category. If the household 
Table 7 Instrumental variable two part model for share of households' expenditures on human, physical and financial assets

\begin{tabular}{|c|c|c|c|c|c|c|}
\hline \multirow[t]{2}{*}{ Variables } & \multicolumn{4}{|c|}{ First part } & \multicolumn{2}{|c|}{ Second part } \\
\hline & Coefficient & $\begin{array}{l}\text { Robust } \\
\text { S.E. }\end{array}$ & $\begin{array}{l}\text { M.E. on Prob } \\
(\mathrm{Y}>0)\end{array}$ & $\begin{array}{l}\text { Robust } \\
\text { S.E. }\end{array}$ & $\begin{array}{l}\text { Coefficient/M.E. } \\
\text { on } E(Y \mid Y>0)\end{array}$ & $\begin{array}{l}\text { Robust } \\
\text { S.E. }\end{array}$ \\
\hline $\begin{array}{l}\text { HH remittance income } \\
(1,000 \text { pesos) }\end{array}$ & $0.013^{* * *}$ & 0.002 & $0.003^{* * *}$ & 0.001 & 0.004 & 0.003 \\
\hline Remittance income volatility & $0.070^{* *}$ & 0.031 & $0.017^{* *}$ & 0.007 & $0.070^{* *}$ & 0.029 \\
\hline Female headed $\mathrm{HH}$ & $-0.017^{*}$ & 0.010 & $-0.004^{*}$ & 0.002 & 0.004 & 0.011 \\
\hline $\begin{array}{l}\text { Number of young children } \\
\text { in the } \mathrm{HH}\end{array}$ & 0.010 & 0.006 & 0.002 & 0.002 & $-0.031^{* * *}$ & 0.006 \\
\hline Number of elderly $\mathrm{HH}$ members & $-0.100^{* * *}$ & 0.007 & $-0.024^{* * *}$ & 0.002 & $-0.028^{* * *}$ & 0.007 \\
\hline $\begin{array}{l}\text { Number of } \mathrm{HH} \text { members with } \\
\text { high school or above }\end{array}$ & $0.105^{* * *}$ & 0.006 & $0.025^{* * *}$ & 0.001 & -0.021 & 0.019 \\
\hline $\begin{array}{l}\text { Number of } \mathrm{HH} \text { members with } \\
\text { middle school }\end{array}$ & $0.071^{* * *}$ & 0.004 & $0.017^{* * *}$ & 0.001 & 0.014 & 0.008 \\
\hline Number of $\mathrm{HH}$ members employed & $-0.012^{* * *}$ & 0.005 & $-0.003^{* * *}$ & 0.001 & $-0.038^{* * *}$ & 0.007 \\
\hline $\begin{array}{l}\text { HH Income excluding remittances } \\
\text { (in 1,000 pesos) }\end{array}$ & $0.002^{* * *}$ & 1.5E-04 & $0.001^{* * *}$ & 4.0E-05 & $0.001^{* * *}$ & $1.9 \mathrm{E}-04$ \\
\hline $\begin{array}{l}\text { Uncertainty of HH income } \\
\text { excluding remittances }\end{array}$ & 0.002 & 0.011 & 4.1E-04 & 0.003 & $0.122^{* * *}$ & 0.030 \\
\hline Household size & $0.051^{* * *}$ & 0.003 & $0.012^{* * *}$ & 0.001 & $0.033^{* * *}$ & 0.004 \\
\hline Rural household & $-0.123^{* * *}$ & 0.010 & $-0.030^{* * *}$ & 0.003 & $0.088^{* * *}$ & 0.024 \\
\hline Year fixed-effects & \multicolumn{4}{|c|}{ Yes } & \multicolumn{2}{|l|}{ Yes } \\
\hline Mexican state fixed-effects & \multicolumn{4}{|c|}{ Yes } & \multicolumn{2}{|l|}{ Yes } \\
\hline Mexican state-level time trends & \multicolumn{4}{|c|}{ Yes } & \multicolumn{2}{|l|}{ Yes } \\
\hline Observations: & \multicolumn{4}{|c|}{159,523} & \multicolumn{2}{|l|}{125,992} \\
\hline Significance & \multicolumn{4}{|c|}{$\begin{array}{c}\text { Wald Chi } 2=31,488.69 \\
\text { with Prob }>\text { Chi } 2=0.000\end{array}$} & \multicolumn{2}{|c|}{ R-squared $=0.112$} \\
\hline
\end{tabular}

Notes: ***Significant at the 1 percent level or better, ${ }^{* *}$ significant at 5 percent level or better and *significant at the 10 percent level or better. All regressions include a constant term. Standard errors are clustered at the Mexican state level. Marginal effects are evaluated at the mean.

experiences a USD 50 (500 peso) increase in remittances per month over the past sixmonths, its likelihood of engaging in asset accumulation would increase by about 1 percentage point. Additionally, the uncertainty of remittance income continues to impact household asset accumulation. Specifically, a one standard deviation increase in the uncertainty of remittance income appears to raise the likelihood of household spending on asset accumulation by approximately 2.2 percentage points $\left(0.017^{*} 1.3\right)$ and the share of household expenditures in this category by approximately 9 percent $(0.07 * 1.3)$, a non-trivial amount ${ }^{30}$.

It is also worth noting that both the level and uncertainty in ordinary income continue to impact asset accumulation. Specifically, a 1,000 peso increase (about USD 100) in ordinary income over the past six months raises the probability that recipients engage in asset accumulation by 0.1 percentage points and increases asset accumulation by 0.1 percent. Hence, using the same figures from earlier, if the household experiences a USD 50 (500 peso) increase in remittances per month over the past six-months, its likelihood of engaging in asset accumulation would increase by about 0.3 percentage points and its share of expenditures on asset accumulation would go up by 0.3 percent. As in the non-instrumented results, uncertainty in ordinary income does not impact 
the household's likelihood of engaging in asset accumulation, but it does affect its share of spending on that category for those engaged in saving. In particular, a one standard deviation increase in non-remittance income volatility raises asset accumulation by 7 percent $(0.579 * 122)$-an impact similar in magnitude to the impact of an increase in remittance income volatility.

Finally, the figures in Table 7 also reveal that households with a larger number of elderly members are less likely to engage in asset accumulation -a finding in line with traditional life-cycle saving models. Elderly members are more likely to consume their accumulated wealth as opposed to accumulate new wealth. We also continue to find that households with a larger number of employed members engage in less asset accumulation. As noted earlier, the employment is likely to be lower in wealthier households owing to the higher reservation wages of their members. If wealthier households are also more likely to engage in greater asset accumulation, the number of working members and the household's asset accumulation should be inversely related. Similarly, we continue to find that the incidence of asset accumulation is lower in rural households, but their shares of spending on asset accumulation are much larger than those of their rural counterparts.

In sum, both the level and uncertainty surrounding remittance flows appear to significantly impact households' asset accumulation patterns in Mexico by impacting their likelihood of engaging in saving and/or the share of spending on human, physical and financial assets.

\section{Summary and conclusions}

Because of the large magnitude of remittance inflows in many developing economies, governments and international organizations have been particularly interested in findings ways to maintain or increase the size of these monetary transfers. Additionally, policymakers and researchers have expressed interest in learning about conditions under which remittance-receiving households will use these inflows for "productive" purposes with the intent of developing policies that may help stimulate asset accumulation.

As predicted by the permanent income hypothesis and precautionary saving theories, we find that the uncertainty surrounding remittance income inflows is a key determinant of asset accumulation in remittance-receiving households. Specifically, a one standard deviation increase in the uncertainty of remittance income raises the likelihood of household spending on asset accumulation by approximately 2 percentage points, or from an average of 12.5 percent to approximately 14.5 percent of remittance-receiving households. Additionally, this increase in remittance income uncertainty raises the share of household expenditures on human, physical and financial assets by between 4 and 9 percent. Therefore, instead of spending 3,000 pesos out of 23,000 pesos on those investments, households increase their expenditures on asset accumulation to anywhere between 3,120 and 3,270 pesos.

We believe that our findings are important because they provide us with a better understanding of household spending patterns crucial for policy-making in developing migrant-sending economies that rely heavily on remittance inflows. Take, for instance, policies regarding remittances from the United States to poor countries. Thus far, these policies have been primarily focused on: i) lowering transactions fees, and ii) integrating 
immigrant populations into the formal financial (banking) sector with the expectation that cheaper and more secure money transfer mechanisms will increase remittance flows. Yet, to date, we know little about the optimal design of these policies. Would we do best encouraging and facilitating large lump-sum transfers? How about smaller, evenly spaced, periodic transfers ${ }^{31}$ ? Will remittance-receiving households respond in one way to transfers that are predictable and in another way to transfers that are less predictable? And, if so, does this help us understand the expenditure patterns of remittance inflows in various emigrant-sending economies? Our intent has been to learn about the conditions under which remittances are more likely to promote asset accumulation. We believe that our findings suggest that the predictability of remittance income should be given full consideration in order to better comprehend how households spend remittances and, accordingly, in the design of policies that leverage the most out of remittance inflows into developing economies.

\section{Endnotes}

${ }^{1}$ Our focus is on how the level and predictability of remittance flows impact the use that remittance-receiving households ultimately make of those funds other things constant. We acknowledge that senders might have a preference for how the money being sent is to be spent. However, remittance-receiving households might have different priorities, as shown in various remittance surveys. Hence, learning how remittancereceiving households respond to both the magnitude and the predictability of the inflows is crucial in explaining the end use of these funds.

${ }^{2}$ See, for example, Friedman (1957), Ando and Modigliani (1957), Modigliani and Brumberg (1954). This idea is articulated and tested in a study by Adams (1998), where he finds that remittance income (in contrast to regular income) is more likely to be spent on farming investments in rural Pakistan. Remittances are viewed as temporary income relative to other sources of income earned by the rural household and, hence, they were regarded as less suitable for financing recurring consumption expenditures. Our hypothesis differs in that we distinguish regular and predictable remittance income from irregular and less predictable remittance income. Households with regular/predictable remittance inflows will likely engage in more consumption, while households with less regular/unpredictable remittance income are likely to engage in more asset accumulation, all other things equal.

${ }^{3}$ Throughout this study we will use the terms uncertainty, irregular and volatility interchangeably when describing the steam of remittance received by the household. While each of these terms may be defined more precisely we use the terms to simply convey the level of variability in the stream of inflows.

${ }^{4}$ Fernández-Villaverde and Krueger (2007) make a case for including durable asset accumulation when studying life-cycle saving in the U.S. They suggest that, especially early in the life-cycle, households use durable assets to insure against income shocks.

${ }^{5}$ See Table 8 in the Appendix for details on variable definitions.

${ }^{6}$ For instance, the survey collects information on respondents' age, gender, relationship to the household head, marital status, as well as educational attainment and employment. Additionally, the survey gathers detailed information on the housing unit and living conditions of the household and income inflows. 
${ }^{7}$ Other Mexican surveys containing nationally representative information on household income and expenditures, such as the Mexican Life Family Survey, do not allow us to: (1) Distinguish between domestic and international remittance transfers, and (2) Do not contain detailed month to month income information required to construct measures of remittance income uncertainty. Similarly, the Mexican census only reports last month's receipts.

${ }^{8} \mathrm{We}$ also experiment with alternative measures of remittance income volatility, such as the rolling standard deviation of month-to-month percentage changes in remittance inflows during the past six months. Our main findings prove robust to the use of this alternative measure. Results are available from the authors.

${ }^{9}$ This measure is thus derived from retrospective data in that the respondent is asked to recall remittance inflows in each of the past six months. One might question the accuracy of retrospective data on remittance inflows due to the possibility of recall bias. But, since our objective is to measure the spending patterns of households conditioned on their expectations of future remittance inflows, the respondent's recollection of the pattern will likely incorporate those expectations-the variable we are ultimately interested in for our analysis.

${ }^{10}$ For instance, simple tabulations using the Spanish survey of immigrants (2007 Encuesta Nacional de Inmigrantes) carried out by Spain's Instituto Nacional de Estadística reveal that up to 74 percent of immigrants remit money home more than twice a year.

${ }^{11}$ Table 8 in the Appendix includes a description of the various expenditure categories being examined as well as of the remaining variables of interest to this study.

${ }^{12}$ Peso figures are deflated using the Mexican CPI with 1999-2000 as the base year (International Financial Statistics database, International Monetary Fund). We used the average exchange rate (11.24 pesos per dollar) over the time period under consideration (2000-2012) to convert pesos into U.S. dollars.

${ }^{13}$ As noted earlier, our measure of remittance income volatility is intended to proxy for predicted remittance income uncertainty. Therefore, we use the terms volatility and uncertainty interchangeably throughout the study.

${ }^{14}$ This includes the number of young children and elderly household members, as well as whether the household is single female headed.

${ }^{15}$ Owing to the arguably endogeneity of the level and volatility of other sources of household income, we also estimate a parsimonious model specification that excludes those variables. Results are displayed in the Appendix under Tables 9 and 10. Our key findings prove robust to the use of this alternative specification.

${ }^{16}$ The ENIGH is a cross-sectional dataset; therefore, we are unable to account for household level heterogeneity, which creates the potential for an omitted variable bias on the coefficient of interest -an issue that can be addressed by appropriately instrumenting for remittance income uncertainty as we propose doing in the present study.

${ }^{17}$ According to other surveys of remittances, very few remitters claim to remit at frequencies lower than twice a year. As noted earlier, the relatively recent Spanish survey of immigrants reveals that up to 74 percent of immigrants send money home more often than twice a year. Additionally, according to a survey of immigrants in San Diego 
County (the SDSU San Diego Area Study: Immigrants and Immigration Issues from October 2005), only 1.8 percent of those who claim to send remittances to Mexico remit at frequencies of once a year or less. And, according to the August 2008 CPS migration supplement, 70 percent of U.S. immigrants who send monetary transfers home, remit at frequencies greater than twice a year (Grieco et al., 2010).

${ }^{18}$ Details concerning the construction of these instruments are provided in the Appendix.

${ }^{19} \mathrm{We}$ are not able to run over-identification tests. However, we informally explore whether our instruments help explain asset accumulation. They are never statistically different from zero regardless of the model specification object of analysis. Results are available from the authors.

${ }^{20}$ The ENIGH lacks information on household wealth.

${ }^{21}$ We know, for instance, that female-headed households are much more likely to have experienced the out-migration of household members.

${ }^{22}$ The Breusch-Pagan/Cook-Weisberg test for heteroscedasticity rejects the null hypothesis of a homoscedastic error term with Prob $>$ Chi2 $=0.000$.

${ }^{23}$ The Shapiro-Wilk test for normality rejects the null hypothesis of normally distributed data with Prob $>\mathrm{z}=0.000$.

${ }^{24}$ Other ways of modeling heteroscedastic and non-normally distributed outcomes include censored least absolute deviation (CLAD) models and, to a lesser degree, censored quantile regression methods. Both methods present important challenges in our case. Generally, quantile methods do not address the problem of heteroscedasticity, whereas the CLAD models prove to be computationally unfeasible due to the size of the dataset and the numerous regressors included in the model.

${ }^{25}$ Please refer to Table 8 in the Appendix for additional details.

${ }^{26}$ Note that remittance income in the regression equation is measured in thousands of pesos (see Table 8 in the Appendix).

${ }^{27}$ The standard deviation of the coefficient of variation of remittance income variability is 0.89 An example of what such an increase is remittance income uncertainty represents would be given by a household switching from receiving a steady monthly inflow of 2,233 pesos/month during a six-month period, to receiving the following inflow over the same time span: 5,000 pesos in the first month, 0 pesos in the second month, 0 pesos in the third month, 2,000 pesos in the fourth month, 3,200 pesos in the fifth month and 3,200 in the sixth month.

${ }^{28}$ The standard deviation of the coefficient of variation of household income excluding remittances is 0.579 .

${ }^{29}$ Please refer to the Appendix for specific details on the construction of the three instruments.

${ }^{30}$ The standard deviation of the coefficient of variation of the instrumented remittance income uncertainty is 1.3 .

${ }^{31}$ For example, preliminary reports from a field experiment by Aycinena et al. (2010) suggest that lowering remittance fees induce Salvadorian emigrants to send a larger annual amount, but also to send remittances more frequently, for example, every month instead of quarterly. This might translate into a more predictable flow for the recipients even though the authors do not specifically test whether that is the case. 


\section{Appendix}

Names and definitions for each of the variables used in this article are described in Table 8.

Table 8 Variable names and definition

Variable name
Human capital investment
Educational investments
Health investments
Physical capital investment
Real estate investments
(i.e. housing, land, etc.)
Business investments
(i.e. micro-enterprises)
Purchase of durable assets

\section{Financial investment}

Financial investments (e.g. bank deposits, stock, etc.)

Dependent variable

\section{Share of expenditures on Human, Physical and Financial Assets}

Independent variables:

Uncertainty in remittance income Remittance income (in 1,000 pesos)

$\mathrm{HH}$ Income excluding remittances (in 1,000 pesos)

Uncertainty in $\mathrm{HH}$ income excluding remittances

Female headed $\mathrm{HH}$

Number of young children in the $\mathrm{HH}$ Number of elderly $\mathrm{HH}$ members

Number of $\mathrm{HH}$ members with high school or above

Number of $\mathrm{HH}$ members with middle school

Number of $\mathrm{HH}$ members employed

Household size

Rural household

U.S. unemployment rate volatility

U.S. earnings volatility
Definition

Expenditures on primary, secondary and higher education, educational services (tutoring, boarding, transportation to school, etc.), and educational goods (books, school items, repair of school items, etc.).

All health related expenditures, including medicines with and without a prescription, glasses, etc., but excluding health insurance.

Real estate purchases, mortgage payments, and maintenance and repair of property.

Business investments and business related purchases, e.g. machinery, tools, livestock, etc.

Purchase of home related durable assets, such as a washing machine, refrigerator or a television.

Deposits in bank accounts; loans to third parties; purchase of foreign currency, jewelry, art and alike valuables; purchase of stock, bonds and financial assets; purchase of brand names, patents, and author rights.

(Educational Investments + Health Investments + Real Estate Investments + Business Investments + Financial Investments + Purchase of Durable Assets)/total household expenditures over the past quarter.

Coefficient of variation of remittance income over the past six months. Gifts and donations from abroad during the past six months.

All household income excluding gifts and donations from abroad (e.g. income from work, own businesses, coops, rents from real estate and financial assets, income transfers, and other sources of income, such as revenues from selling a car or household goods) during the past six months.

Coefficient of variation of household income excluding remittances over the past six months.

Household head is female.

Number of household members 6 years old and younger.

Number of household members 65 years of age and older.

Number of household members with university and higher education (i.e. superior and posgrado).

Number of household members with secondary education or vocational training (i.e. secundaria, preparatoria, vocacional and normal). Number of household members employed.

Household size.

Household resides in an area with fewer than 2,500 inhabitants.

Weighted average of standard deviation of monthly unemployment rates. Weights reflect the incidence of migration from the Mexican state in question to U.S. destinations.

Standard deviation of weekly earnings in U.S. states that are destinations for Mexican emigrants. Weights reflect the incidence of migration from the Mexican state in question to U.S. destinations. 


\section{Instruments}

To construct our instruments, we used the Mexican Migration Project (MMP118) database to obtain information on emigration patterns for each Mexican state. The MMP118 reveals the U.S. state of residency of return migrants. Using that information, we derive weights for the likely U.S. destinations of current Mexican emigrants from each Mexican state. These are used to construct weighted averages of U.S. unemployment volatility and U.S. earnings volatility for emigrants from each of the Mexican states in the ENIGH during each survey period.

About 31 percent of return migrants in the Mexican state of Durango resided in California, 28 percent resided in Texas, 26 percent in Illinois and 15 percent elsewhere in the United States. To obtain a measure of uncertainty in U.S. unemployment in 2000, we compute the standard deviation in month-to-month unemployment in each U.S. state during 2000. The information on migration networks derived from the MMP118 is then applied to compute a weighted average of the standard deviation of month-to-month U.S. unemployment during 2000. For example, using the pattern of emigration from the Mexican state of Durango to the U.S. we compute the following weighted average of U.S. unemployment volatility for emigrants from Durango: $\left(0.31^{*} \mathrm{u}_{\mathrm{CA}}+0.28^{*} u_{\mathrm{TX}}+0.26^{*} u_{\mathrm{IL}}+0.15^{*} u_{\mathrm{US}}\right)$ where, for instance, $\mathrm{u}_{\mathrm{CA}}$ represents the variability of unemployment (measured as the standard deviation of the series of unemployment rates) in California during 2000 according to unemployment series from MORG extracts of the CPS.

To obtain a measure of uncertainty in U.S. earnings in the year 2000, we compute the standard deviation of percentage changes in month-to-month earnings in each U.S. state during 2000. The information on migration networks derived from the MMP118 is then applied to compute a weighted average of the standard deviation of percentage changes in month-to-month U.S. earnings during the year 2000. For example, using the pattern of emigration from the Mexican state of Durango to the U.S. we compute the following weighted average of U.S. earnings uncertainty for emigrants from Durango: $\left(0.31 * \mathrm{~S}_{\mathrm{CA}}+0.28 * S_{\mathrm{TX}}+0.26 * S_{\mathrm{IL}}+0.15 * S_{\mathrm{US}}\right)$ where, for instance, $\mathrm{S}_{\mathrm{CA}}$ represents the variability of earnings (measured as the standard deviation of percentage changes in month to month earnings) in California during 2000 according to the earnings series from MORG extracts of the CPS. The weighted average of the volatility series proxies the uncertainty of earnings of emigrants from the state of Durango in 2000 .

These instruments help predict remittance income and its uncertainty. Yet, we have no a priori reason to believe that these instruments may be correlated to household expenditure patterns in Mexico other than through remittances themselves. Our identifying assumption is that current U.S. labor market conditions do not affect the expenditure patterns of Mexican residents other than through remittances. After all, wages and unemployment rates in Mexican emigrant U.S. destination states are derived from information on state-level migration networks from a different survey and, as such, do not reflect individual household level migration choices. The same can be argued with regards to the uncertainty measure. These weighted U.S. unemployment, weighted earnings and earnings volatility series are used as instruments for the remittance flows received by households in various Mexican states and survey years. 
Table 9 Two part model for share of households' expenditures on human, physical and financial assets

\begin{tabular}{|c|c|c|c|c|c|c|}
\hline \multirow[b]{2}{*}{ Variables } & \multicolumn{4}{|c|}{ First part } & \multicolumn{2}{|c|}{ Second part } \\
\hline & Coefficient & $\begin{array}{l}\text { Robust } \\
\text { S.E. }\end{array}$ & $\begin{array}{c}\text { M.E. on } \\
\text { Prob }(Y>0)\end{array}$ & $\begin{array}{l}\text { Robust } \\
\text { S.E. }\end{array}$ & $\begin{array}{l}\text { Coefficient/M.E. } \\
\text { on } E(Y \mid Y>0)\end{array}$ & $\begin{array}{c}\text { Robust } \\
\text { S.E. }\end{array}$ \\
\hline $\begin{array}{l}\text { HH remittance income } \\
(1,000 \text { pesos })\end{array}$ & $0.011^{* * *}$ & 0.001 & $0.003^{* * *}$ & 0.000 & $0.011^{* * *}$ & 0.001 \\
\hline Remittance income volatility & $0.080^{* * *}$ & 0.015 & $0.019^{* * *}$ & 0.004 & $0.053^{* * *}$ & 0.018 \\
\hline Female headed $\mathrm{HH}$ & $-0.033^{* * *}$ & 0.010 & $-0.008^{* * *}$ & 0.002 & -0.012 & 0.012 \\
\hline $\begin{array}{l}\text { Number of young children } \\
\text { in the } \mathrm{HH}\end{array}$ & $0.012^{*}$ & 0.006 & $0.003^{*}$ & 0.002 & $-0.029^{* * *}$ & 0.006 \\
\hline Number of elderly $\mathrm{HH}$ members & $-0.103^{* * *}$ & 0.007 & $-0.025^{* * *}$ & 0.002 & $-0.029^{* * *}$ & 0.007 \\
\hline $\begin{array}{l}\text { Number of } \mathrm{HH} \text { members with } \\
\text { high school or above }\end{array}$ & $0.152^{* * *}$ & 0.005 & $0.036^{* * *}$ & 0.001 & 0.013 & 0.020 \\
\hline $\begin{array}{l}\text { Number of } \mathrm{HH} \text { members with } \\
\text { middle school }\end{array}$ & $0.080^{* * *}$ & 0.004 & $0.019 * * *$ & 0.001 & $0.019^{* *}$ & 0.009 \\
\hline Number of $\mathrm{HH}$ members employed & -0.001 & 0.004 & 0.000 & 0.001 & $-0.031^{* * *}$ & 0.007 \\
\hline Household size & $0.049^{* * *}$ & 0.003 & $0.012^{* * *}$ & 0.001 & $0.029^{* * *}$ & 0.004 \\
\hline Rural household & $-0.138^{* * *}$ & 0.010 & $-0.034^{* * *}$ & 0.003 & $0.092^{* * *}$ & 0.025 \\
\hline Year fixed-effects & \multicolumn{4}{|c|}{ Yes } & \multicolumn{2}{|l|}{ Yes } \\
\hline Mexican state fixed-effects & \multicolumn{4}{|c|}{ Yes } & \multicolumn{2}{|l|}{ Yes } \\
\hline Mexican state-level time trends & \multicolumn{4}{|c|}{ Yes } & \multicolumn{2}{|l|}{ Yes } \\
\hline Observations: & \multicolumn{4}{|c|}{159,940} & \multicolumn{2}{|l|}{126,123} \\
\hline Significance & \multicolumn{4}{|c|}{$\begin{array}{l}\text { Wald Chi } 2=31,390.30 \text { with } \\
\quad \text { Prob }>\text { Chi } 2=0.000\end{array}$} & \multicolumn{2}{|c|}{ R-squared $=0.107$} \\
\hline
\end{tabular}

Notes: ** Significant at the 1 percent level or better, ${ }^{*}$ significant at 5 percent level or better and ${ }^{*}$ significant at the 10 percent level or better. All regressions include a constant term. Standard errors are clustered at the Mexican state level. Marginal effects are evaluated at the mean.

Table 10 Instrumental variable two part model for share of households' expenditures on human, physical and financial assets

\begin{tabular}{|c|c|c|c|c|c|c|}
\hline \multirow[b]{2}{*}{ Variables } & \multicolumn{4}{|c|}{ First part } & \multicolumn{2}{|c|}{ Second part } \\
\hline & Coefficient & $\begin{array}{l}\text { Robust } \\
\text { S.E. }\end{array}$ & $\begin{array}{c}\text { M.E. on } \\
\text { Prob }(Y>0)\end{array}$ & $\begin{array}{l}\text { Robust } \\
\text { S.E. }\end{array}$ & $\begin{array}{l}\text { Coefficient/ M.E. } \\
\text { on } E(Y \mid Y>0)\end{array}$ & $\begin{array}{l}\text { Robust } \\
\text { S.E. }\end{array}$ \\
\hline $\begin{array}{l}\text { HH remittance income } \\
(1,000 \text { pesos })\end{array}$ & $0.011^{* * *}$ & 0.002 & $0.003 * * *$ & 0.001 & $0.005^{*}$ & 0.003 \\
\hline Remittance income volatility & $0.076^{* * *}$ & 0.031 & $0.018^{* * *}$ & 0.007 & $0.083^{* * *}$ & 0.029 \\
\hline Female headed $\mathrm{HH}$ & $-0.035^{* * *}$ & 0.010 & $-0.009^{* * *}$ & 0.002 & -0.009 & 0.012 \\
\hline $\begin{array}{l}\text { Number of young children } \\
\text { in the } \mathrm{HH}\end{array}$ & $0.012^{*}$ & 0.006 & $0.003^{*}$ & 0.002 & $-0.029^{* * *}$ & 0.006 \\
\hline Number of elderly HH members & $-0.103^{* *}$ & 0.007 & $-0.025^{* * *}$ & 0.002 & $-0.029^{* * *}$ & 0.007 \\
\hline $\begin{array}{l}\text { Number of } \mathrm{HH} \text { members with } \\
\text { high school or above }\end{array}$ & $0.152^{* * *}$ & 0.005 & $0.037^{* * *}$ & 0.001 & 0.014 & 0.020 \\
\hline $\begin{array}{l}\text { Number of } \mathrm{HH} \text { members with } \\
\text { middle school }\end{array}$ & $0.080^{* * *}$ & 0.004 & $0.019^{* * *}$ & 0.001 & $0.020^{* *}$ & 0.009 \\
\hline Number of HH members employed & -0.001 & 0.004 & 0.000 & 0.001 & $-0.033^{* * *}$ & 0.007 \\
\hline Household size & $0.049^{* * *}$ & 0.003 & $0.012^{* * *}$ & 0.001 & $0.029^{* * *}$ & 0.004 \\
\hline Rural household & $-0.141^{* * *}$ & 0.010 & $-0.035^{* * *}$ & 0.003 & $0.092^{* * *}$ & 0.025 \\
\hline
\end{tabular}


Table 10 Instrumental variable two part model for share of households' expenditures on human, physical and financial assets (Continued)

\begin{tabular}{lcc}
\hline Year fixed-effects & Yes & Yes \\
Mexican state fixed-effects & Yes & Yes \\
Mexican state-level time trends & Yes & Yes \\
Observations: & 159,940 & 126,123 \\
Significance & Wald Chi2 $=31,406.77$ with & R-squared $=0.107$ \\
\end{tabular}

Notes: ***Significant at the 1 percent level or better, ${ }^{* *}$ significant at 5 percent level or better and ${ }^{*}$ significant at the 10 percent level or better. All regressions include a constant term. Standard errors are clustered at the Mexican state level. Marginal effects are evaluated at the mean.

Table 11 First stage tobit models predicting remittance income and remittance income uncertainty

\begin{tabular}{|c|c|c|c|c|}
\hline \multirow[t]{2}{*}{ Independent variables } & \multicolumn{2}{|c|}{ Remittance income } & \multicolumn{2}{|c|}{ Remittance income volatility } \\
\hline & Coefficient & Robust S.E. & Coefficient & Robust S.E. \\
\hline Unemployment rate volatility & $-359.988^{* * *}$ & 130.535 & $-42.204^{* * *}$ & 15.794 \\
\hline U.S. earnings volatility & $-104.231^{* * *}$ & 24.900 & $-8.959^{* * *}$ & 3.068 \\
\hline Number of observations & \multicolumn{2}{|c|}{159,523} & \multicolumn{2}{|c|}{153,430} \\
\hline Uncensored observations & \multicolumn{2}{|c|}{9,441} & \multicolumn{2}{|c|}{6,093} \\
\hline \multicolumn{5}{|l|}{ Joint F-statistic of the NVs: } \\
\hline F-statistic & \multicolumn{2}{|c|}{13.35} & \multicolumn{2}{|c|}{8.34} \\
\hline Prob $>$ F & \multicolumn{2}{|c|}{0.0000} & \multicolumn{2}{|c|}{0.0000} \\
\hline
\end{tabular}

Notes: ***Significant at the 1 percent level or better, ${ }^{* *}$ significant at 5 percent level or better and *significant at the 10 percent level or better. The regressions also include a constant and all other regressors in Table 7. Standard errors are clustered at the state level.

Competing interests

The IZA Journal of Labor \& Development is committed to the IZA Guiding Principles of Research Integrity. The authors declare that they have observed these principles.

\section{Acknowledgements}

We are grateful to the BBVA Foundation for financial support of this research. The BBVA Foundation placed no restrictions on the outcome of this research. We are also grateful to Myriam Quispe-Agnoli and participants at the "Remittances and the Macro-Economy" conference at the Federal Reserve Bank of Atlanta, at the Population Association of America meetings, and at the Society for Labor Economists meetings. We are also grateful to an anonymous referee for useful comments.

Responsible editor: Jackline Wahba

\section{Author details}

${ }^{1}$ Department of Economics, San Diego State University, San Diego, CA 92182, USA. ²Department of Economics, Western Michigan University, Kalamazoo, MI 49008, USA.

Received: 27 November 2013 Accepted: 14 February 2014

Published: 19 Mar 2014

\section{References}

Adams RH Jr (1998) Remittances, investment and rural asset accumulation in Pakistan. Econ Dev Cult Chang 47:155-173 Adams RH Jr (2005) "Remittances, Household Expenditures and Investment in Guatemala" World Bank Policy Research Working Paper 3532., Available via http://dx.doi.org/10.1596/1813-9450-3532. Accessed February 8, 2014 Adams RH Jr (2011) Evaluating the economic impact of international remittances on developing countries using household surveys: a literature review. J Dev Stud 47(6):809-828

Airola J (2007) The use of remittance income in Mexico. Int Migr Rev 41(4):850-859

Ando A, Modigliani F (1957) Tests of the life cycle hypothesis of saving. Bull Inst Econ Stat (Oxford University) 19:99-124 Aycinena D, Martinez CA, Yang D (2010) The Impact of Remittance Fees on Remittance Flows: Evidence from a Field Experiment Among Salvadorian Migrants. University of Michigan, Available at http://www-personal.umich.edu/ deanyang/ papers/aycinena\%20martinez\%20yang\%20-\%20remittances.pdf accessed 2/8/2014 
Brown RPC (1997) Estimating remittance functions for Pacific Island migrants. World Development 25(4):613-626 Chiodi V, Jaimovich E, Montes-Rojas G (2012) Migration, remittances and capital accumulation: evidence from rural Mexico. J Dev Stud 48(8):1139-1155

Durand J, Kandel W, Parrado E, Massey D (1996) International migration and development in Mexican communities. Demography 33(2):249-264

Fernández-Villaverde J, Krueger D (2007) Consumption over the life cycle: facts from consumer expenditure survey data. Rev Econ Stat 89(3):552-565

Friedman M (1957) A theory of the consumption function. Princeton University Press, Princeton, NJ

Glytsos NP (1993) Measuring the income effects of migrant remittances: a methodological approach applied to Greece. Econ Dev Cult Chang 42(1):131-168

Grieco EM, de la Cruz P, Cortes R, Larsen L (2010) Who in the United States sends and receives remittances? An initial analysis of the monetary transfers data from the August 2008 CPS Migration Supplement, Immigration Statistics Staff, Population DivisionWorking Paper No. 87., Available via http://www.census.gov/population/www/ documentation/twps0087/twps0087.html. Accessed February 8, 2014

Kandel W, Kao G (2001) The impact of temporary labor migration on Mexican children's educational aspirations and performance. Int Migr Rev 35(4):1205-1231

Keely CB, Tran BN (1989) Remittances from labor migration: Evaluations, performance and implications. Int Migr Rev 23:500-525

Leland HE (1968) Saving and uncertainty: the precautionary demand for saving. Q J Econ 82:465-473

Modigliani F, Brumberg R (1954) Utility analysis and the consumption function: an interpretation of cross-section data. In: Kurihara KK (ed) Post-Keynesian economics. Rutgers University Press, New Brunswick, NJ

Mora J, Taylor JE (2006) Does migration reshape expenditures in rural households? Evidence from Mexico. World Bank Policy Research Working Paper No. 3842., Available at SSRN: http://ssrn.com/abstract=922968

Ravallion M, Dearden L (1988) Social security in a 'moral economy': An empirical analysis for Java. Review of Economics and Statistics 70(1):36-44

Schrieder G, Knerr B (2000) Labour migration as a social security mechanism for smallholder households in Sub-Saharan Africa: The case of Cameroon. Oxford Development Studies 28(2):223-236

Senbeta A (2013) Remittances and the sources of growth. Appl Econ Lett 20(4-6):572-580

Wooldridge JM (2009) Introductory Econometrics: A Modern Approach. South-Western Cengage Learning, Mason OH

Zarate-Hoyos GA (2004) Consumption and remittances in migrant households: toward a productive use of remittances. Contemp Econ Policy 22(4):555-565

10.1186/2193-9020-3-3

Cite this article as: Amuedo-Dorantes and Pozo: Remittance income uncertainty and asset accumulation. IZA

Journal of Labor \& Development 2014, 3:3

Submit your manuscript to a SpringerOpen ${ }^{\circ}$ journal and benefit from:

- Convenient online submission

- Rigorous peer review

- Immediate publication on acceptance

- Open access: articles freely available online

- High visibility within the field

- Retaining the copyright to your article

Submit your next manuscript at $\boldsymbol{\nabla}$ springeropen.com 